\title{
A Social Semiotic Study of Online Comments on Underwear Ritual Discourse in Nairaland
}

\author{
Bankole Idowu AKINWANDE, Ph.D. \\ Department of English \\ Adeyemi College of Education \\ Ondo, Nigeria.
}

\begin{abstract}
This study investigates underwear ritual discourse in Nairaland, focusing on social semiotic approach. It particularly explores how language and attitude interact explicitly to communicate attitudinal meaning in this discussion board. Findings show that explicit linguistic realisations such as amplifiers, interrogatives, and symbolism are significant to explicating revolutionary, expository, sarcastic, indifferent, condemnatory and justificatory attitudes. From these attitudes, not many of the commenters are against crime, but very many of them seem to suggest that the solution to the subject of criminality is not in the hands of individuals; it lies in the hands of government. The study therefore concludes that online environment has provided a semiotic space for people to register their involvement in the sociopolitical and economic events of the country.
\end{abstract}

Keywords: Social Semiotics, underwear ritual discourse, language, attitude, explicit linguistic realisations, Nairaland.

\section{Introduction}

Although, various theories of language have been propounded to explicate the significance of meaning in language, particularly as currently used on social media, the place of social semiotic approach cannot be overemphasized. If meaning in dialogue is socially constructed (Taiwo, 2016), then, a theory of social relevance as social semiotics, which studies the material resources of communication (i.e. significations) and the ways their uses are socially regulated (Leeuwen, 2005), is essential to meaning production in contemporary social discourses. One striking aspect of the theory, which the present study is premised on, is its quest for the manner in which signs and attitude interact to communicate attitudinal meaning. Studies on social semiotics have approached it from different perspectives. A group of studies has focused on the ways conflicts are prevented and managed in the cyber conversations (Oha, 2006; Lipsky \& Avgar, 2010; Wennmann, 2014). Others have focused on linguistic premises such as gender discourse (Adegoju, 2011); medical discourse (Adegbite \& Odebunmi, 2006; Odebunmi, 2006); political discourse (Oyeleye \& Osisanwo, 2013; Ademilokun \& Olateju, 2016; Lirola, 2016); cultural discourse (Couthard \& Leeuwen, 2003; Matinec, 2003; Solomon-Etefia \& Uwoya, 2017); Advertorial discourse (Olaosun 2006; Schammann 2010; Adegoju \& Ademilokun 2015). However, none of these studies has adopted the method of social semiotics, with particular emphasis on implicit realisations, to investigate crime-related discourse on social media in Nigeria.

The scope of scholarship in social semiotics has tremendously advanced lately, as a result of advancement in social media discourse. In the words of Taiwo (2016:1), "the cyberspace has presented myriads of opportunities for engagement in public sphere discussions." It has offered increasing opportunities for its users to comment on any news posted online (Herring, 2001). It has also enabled users to post their comments about a topic and comment on other writings, while taking their time to read and write messages (Chiluwa, 2010). This online forum, according to Mentzer (2003) has helped greatly in promoting civic discourse and proffering civic solutions through the sharing of similar and different views among participants. This shows how engaging the online platform has been in recent times with regard to topical issues of national interest. One of those topical issues which has not really received a critical attention in scholarship, especially in respect of the theory of social semiotics, is the issue of criminality. It is no more news that criminality has given a voice to insecurity in the country, and studying this phenomenon on social media will show how the different sections of the Nigerian community, which constitute the online environment, represent and react to the socially disturbing matters of crime in Nigeria.

\section{Underwear Ritual Discourse In Nigeria}

The question of security in every human society cannot be underestimated. As a matter of fact, the primary duty of a government should be to keep its citizens safe physically, psychologically, emotionally and financially. Adeleke (2013) avers that one of the fundamental human rights of the people in any given state is the right to security. This is why there is always a provision for security in the constitution of most sovereign states. 
For instance in Nigeria, the nation's 1999 constitution overtly states that the security of the people shall be the primary purpose of the government; but instead, insecurity has been the order of the day. Lately, the phenomenon has attained a sordid peak in the country. Citizens could hardly go about their normal daily activities without any threats to their lives and properties. To echo Achumba, Ighomeroho, \& Akpor-Robaro (2013), the country has consistently witnessed an unprecedented level of insecurity, which has made national security-threat a major issue for the government. Over the years, acts of terrorismby the Boko Haram insurgents in the North, Fulani herdsmen attack in the middle belt region of the country, and several incidents of kidnapping, including agitations by militants in the Niger Delta, have incessantly threatened the security of citizens of Nigeria.

In the recent past, the spate of killings for ritual purposes assumed an alarming rate in the country, with little or no effort by concerned government agencies to checkmate the trend. Some politicians and government officials had even been accused by arrested suspects of using human beings for rituals in order to sustain their affluence as well as remain in positions of power. At the moment, stealing of female panties and used sanitary pads for ritual by Yahoo Boys for Yahoo Plus ritual is the latest trend. The wave of women's pants theft has led to a serious phobia among women in several parts of the country. Not a few outraged women have condemned the act with some of them blaming it on the victims' unguarded conduct. Most disgustingly, in certain areas of the country, ladies now go about pantless just to avoid being dispossessed of their pants, while many others have shunned spreading their pants and braziers on cloth lines in the open. It was gathered that undies, particularly of girls between the ages of 16 and 32 are now hot cakes for ritualists. One pant sells for as high as N250, 000 (The Vanguard, 2019). This act has thus generated civic unrest among citizens of the country, most especially the women folk. Interestingly, the recent phenomenon has not really received a critical attention in scholarship. Doing a social semiotic study of the phenomenon will elucidate the theory and its analytical principles in explicating the selected threads on underwear ritual discourse on Nairaland.

\section{Social Semiotics In Discourse}

Social semiotic approach is a contemporary model of semiotics which is helpful in probing effects of meaning, finding possible answers and even forecasting responses in the context of specific social practices and institutions and in different ways and to different degrees. The theory explores differences among current relations and meanings, historicises and contextualises them, and finally has the main objective of acting on and altering political forces (Leeuwen \& Coulthard, 2003). It indicates an interest in the mode of communication order than language. It is especially interested in how language and other modes of communication combine in multimodal texts and communicative events. The theory studies how meanings are made and how reality is represented in discourse. An interesting aspect of the theory is the system of attitude. Attitude permeates social interactions, as human beings do not communicate in attitudinal limbo. There is always some attitudinal significance attached to the linguistic contents of a message. As a component of social semiotics, attitude can be conveyed or evoked in different ways. The feelings meant here are the feelings that are explicitly stated. The explicit feelings, technically called inscribed attitude, are the feelings that are clear enough to be seen without employing interpretation.

Social semiotics has been studied in different discourse types including medical discourse (Adegbite\&Odebunmi, 2006), gender discourse (Adegoju., 2011), political discourse (Ezeifeka, 2013; Oyeleye \& Osisanwo, 2013), media discourse (Oha, 2006; Afzal \& Harun, 2015; Adegoju, 2016). The literature on social semiotics in online discourse can be divided into two groups: empirical social semiotic research on visual signs (Matinec, 2003; Coulthard \& Leeuwen, 2003; Grunschy, 2007; Mutowo, 2013; Kathryn, 2014), and empirical social semiotic research on linguistic signs (Oha, 2000; Adegbite \& Odebunmi, 2006; Achi, 2008; Hua, 2008; Bennett, 2011; Yeibo, 2011).

Martinec (2003) carries out a social semiotic study of text and image in Japanese and English software manuals and other procedures. The paper presents a comparative analysis of the software manuals. It analyses both the verbal and image components of the texts, in their own right and the way they interact with one another. The analysis focuses on cooking recipes and software manuals but other shorter, procedural texts are also mentioned. The study contends that the Japanese procedures put greater emphasis on the details of the procedural process than the English procedures do. The study concludes that Japanese procedures are found to be more elaborate in the extent with which they engage the reader/viewer.

Van-Leeuwen (2003) does a semiotic analysis of teddy bear stories. The paper sees teddy bears as cultural artifacts that provide a cultural channeling for the child's need of a transitional object and argues that the meanings of teddy bears have traditionally centered on interpersonal relations within the nuclear family, but have recently been institutionalised and commercialized. The study conceives teddy bears as texts in the sense that they are objects whose iconography and kinetic designs communicate symbolic and interactive meanings. The study submits that the attachment to a teddy bear, a doll or a soft toy, a dummy or a blanket signifies an immediate state between a baby's inability and his growing ability to recognise and accept reality. 
Grunschy (2007) investigates Tarsila do Amaral's paintings from a social-semiotic perspective, with the purpose of studying how visual arts, like any other kind of visual communication, convey meanings related to socio-cultural aspects of the society in which they are produced. The study highlights the importance of art in the history of humankind and its relation with cultural paradigms from Prehistoric to Postmodern art. The paper concludes that becoming visually literate can contribute to people's better understanding of meanings in contemporary society.

Solomon-Etefia \& Nweya (2017) explore some semiotic features of selected excerpts of the communiqué made by the Ibadan Catholic Bishops to the congregation on the ebola epidemic. They give a semiotic interpretation of the signs visible, and discuss the impact of the communiqué on the Catholic faithful in the University of Ibadan, Nigeria. The study adopts Saussure's model of semiotic signs as the theoretical framework. It shows that the communiqué is an information-motivated discourse on ebola which comprises direct acts that make use of the contextual features of shared situational knowledge, inferences, relevance, shared cultural knowledge, and references, thereby exhibiting the pragmemes of cautioning, commanding, counseling and threatening. The study concludes that both the pragmemes and the semiotic signs have an impact on the Catholic faithful in University of Ibadan.

The present study is connected to earlier studies because its major preoccupation is social semiotics, which has been handled extensively by the studies reviewed above and many others. While the aspects of the approach to the study of social semiotics in discourse may be similar to earlier studies, the subject matter and the focus of the present study are different in terms of the discourse context. While most of the existing studies focus on semiotics in images and cultural excerpts, the present study basically investigates the discourse of underwear rituals in Nigeria.

\section{Data and Methodology}

The study is anchored on a corpus of 10 postings along with their comments, consisting of 30,259 words, purposively drawn from the online archive of Nairaland forum (www.nairaland.com). Postings/threads selected specifically focused on underwear ritual discourse in Nigeria between. The website is chosen because it has a wide coverage across the country and it is a widely viewed website. Nairaland is a website owned by a Nigerian (SeunOsewa). The website has many discussion sections, which include: politics, entertainment, romance, religion, jokes, culture, fashion, jobs/vacancies, education, crime and sports. The forum which started in 2005, has developed to become the most popular online community associated with Nigeria and Nigerians (Chiluwa, 2010). Taiwo (2016) even claims that Nairaland is Nigeria's largest online forum and discussion portal.

Presently, the website has 2,194,296 members, 4,784,812 topics, and about 6,746 page views per day. The threads of discussion were selected from this portal between January 2018 and January 2019. This period was chosen not only because it captured most recent discussions on crime in the portal, but also because there were a large volume of publications covering various aspects of crime. Data are analysed using Van Leeuwen and Caldas-Coulthad's principles of social semiotics (2003), with emphasis on explicit realisations, as well as system of attitude. The theory is considered fit for the study because it is fundamental to the communicative function of linguistic constructs in specific socio-political and economic contexts.

\section{Data Analysis And Discussion}

Table 1: THREAD A: Police Nab Robbers With Female Underwear, Clothes, Phone- Www.Nairaland.Com, Nov. $14,2018$.

\begin{tabular}{|l|l|}
\hline Comment 1 & $\begin{array}{l}\text { Na wa o. I hear selling used panties is a lucrative business. The stinkier the panties, the } \\
\text { more expensive it is- by Kennygee (f) 9:57am }\end{array}$ \\
\hline Comment 2 & $\begin{array}{l}\text { Nigeria is such a hell because of her whack policemen. The Nigerian police force should } \\
\text { get one fact rightly. I have seen girls who wear male briefs instead of panties. I've seen } \\
\text { men who wear somewhat feminine panties. That you find a man with feminine panties } \\
\text { does not mean it is not his own please!!!But if this case is a case of robbery, they should be } \\
\text { punished for robbery and not for being in possession of female underwear- by } \\
\text { NwaAmaikpe. 9:57 am }\end{array}$ \\
\hline Comment 3 & Bcos things are extremely hard in this country ooo. And man must survive na. \\
\hline Comment 4 & $\begin{array}{l}\text { Na wa o. So robbers don't steal reasonably again. Na so the level of poverty don high } \\
\text { reach?- By Legibow (f). }\end{array}$ \\
\hline Comment 5 & The Nigerian judiciary should raise the standard against crime!!! Raise it boldly. \\
\hline
\end{tabular}




\subsection{Adverbs as Amplifiers of Emotion}

Amplifiers are adverbs that add emotional intensity to sentences. They trigger emotions in readers. They are extensively deployed in the comments to express several negative attitudes and emotions. For instance, comment 3 above intensifies a feeling of distress. The deployment of the adverb of intensity extremely is an indexical representation of hardship in its highest degree, which shows that the pains and sufferings Nigerians are passing through at the moment are unimaginable. The amplifier seems to be interrogating the cause of the current economic recession in Nigeria, in which the masses struggle to live from hands to mouth. There appears to be an attitude of disappointment, particularly in the nation's political figures, whose corrupt activities have largely been identified as the course of the said recession.

Similarly, comment 4 amplifies an explicit attitude of intellectual/social disintegration. The adverb of logic reasonably is an iconic signification of cognitive decadence. The old truth of 'think twice' is no longer applicable to contemporary Nigerian citizens. Even though the country's economy is in recession, as a result of which things are so difficult to cope with, there is a method of human thought that involves thinking in a linear, step-by-step manner about how a problem can be solved. This aspect of logical thinking is conspicuously missing in the attitudes and reactions of the country's current citizens to fundamental issues of national concern. The adoption of the amplifier is a deliberate ridicule of the arbitrary acts of a frustrated class. It is striking to note that the commenter has an indifferent attitude to the act committed (i.e. stealing), which is a way of sitting on the fence. He probably may not be happy with the harsh economic state of the country, which many have seen as the basic reason for an upsurge in crime.

The cause of the commenter's attitude of indifference is not explicitly stated, but his point of emphasis is that logic should be applied to any act committed by the nation's citizens to survive the harsh economy.In other words, whatever anybody is doing to survive the country's economic recession should be done with moderation. For instance, it is logical to reason that stealing money ordinarily for survival may not really affect someone's health (except in a case of hypertension), but stealing for ritual purposes may destroy someone's life forever. The act of stealing for ritual purposes has gone to the extreme and does not portray the nation's citizens as civilized people. If there are myriads of problems such as unemployment, poverty and hunger, among others, the best way to tackle such problems is to entertain the power of understanding, which can only be achieved as a result of rational thinking.

In comment 5, above, the commenter to make a statement about the fragile nature of the nation's judiciary boldly adopts the adverb of manner. It has often been asserted that crime is pronounced in Nigeria because criminals get away with it easily, which is a pointer to the fact that the nation's judiciary is weak. In most criminal cases, the judiciary respects the rich, while the poor are usually made sacrificial lambs. There is a covert feeling of fear, induced by something or someone in the nation's judiciary.

The attitude behind the choice of this amplifier is that the country's judiciary needs resurgence, backed by courage and confidence, to strictly enforce law and order with no regard for any individuals, irrespective of their social status or influence. Similarly in comment 2, the choice of rightly intensifies attitudes of immorality and rebellion in the comment. An attitude of rebellion comes to the fore here because many Nigerians know the right things to do but intentionally choose to do the opposite. The amplifier is adopted to ridicule this recalcitrant attitude and to make request for the nation's citizens to turn over a new leaf.

6. TABLE 2:THREAD 2: Man Caught Wearing 7-Year Old Girl's Pant \& Bra For Rituals At Night In Lagos- One Head 2:44 Pm, July 30, 2018

7.

\begin{tabular}{|l|l|}
\hline Comment 6 & $\begin{array}{l}\text { The economy is not favourable to anyone. So, he is trying to better his life but I don't } \\
\text { expect you to be stupid to this extent by visiting black power to achieve greatness- Jostico. } \\
\text { 2:50pm, Juy 30, 2018 }\end{array}$ \\
\hline Comment 7 & $\begin{array}{l}\text { Pls ladies that hang your undies inside inside room, abi toilet cause you are afraid of } \\
\text { hanging them outside not to be stolen, you are on your own. Your undies need sun, freshair } \\
\text { and proper drynessafter you wash them. Have faith in God. The ritualists' money maker } \\
\text { will surely reject your underwear as you are covered by the blood of the lamb. How careful } \\
\text { can you be? You stay in a hotel, you share room, you have flatmates. } \text { E joo, where you wan } \\
\text { hide your undies biko? Do you hear guys hiding their briefs or boxers? }\end{array}$ \\
\hline Comment 8 & Where are we going in this nation? \\
\hline Comment 9 & $\begin{array}{l}\text { Is this act a by-product of anxiety? What tomorrow will be remains a mystery to many-Gift } \\
\text { (f) }\end{array}$ \\
\hline Comment 10 & This is nothing but social revolution. Which way Nigeria? \\
\hline
\end{tabular}




\subsection{Interrogatives as Evocation of Revolutionary Attitudes}

Questions are a strategy of dialogic involvement in discourses (Osisanwo, 2016). Participants deploy direct and indirect interrogatives to engage interlocutors and bring them into an arena where they can be led to the writer's viewpoint (Hyland, 2002b). As commonly found in the data on TABLE 2 above, the commenters raise rhetorical questions in order to evoke and arouse interlocutors' interest. For instance, in comment 10, the rhetorical question "Which way Nigeria?" is a clarion call: an urgent and inspiring appeal for people to do something. The interrogative is an indexical representation of pandemonium that evokes a feeling of disarray. It brings a truthful realization to both the leaders and the populace of the Nigerian nation that all is far from being well. The comment appears to evince a spirit of political revolution in readers if the challenges facing the masses are not redressed with every sense of urgency. The biggest problem seems to be lack of selfless leadership. As a result of this, the nation has depreciated over the years and it is now riddled with corruption, nepotism, and ineptitude. That there is still life in the country's economy simply means the hand of providence is still on the side of the nation: otherwise, the worse would have happened. The worse is even already happening because things have got really bad for the average Nigerian. Everything that is supposed to enhance economic growth is in shambles and nothing is being done to restructure them. Thus, there is a clear attitude of political revolution in the adoption of the interrogative sentence.

Similarly, the interrogative statements "How careful can you be?" and "E joo, where you wan hide your undies biko?" in comment 7 above, are symbolic significations of aggressive political revolution. It is another way of saying that the sociopolitical and economic problem of the nation has attained its sordid peak. And when citizens of any country of the world hit a peak of frustration with their nation and its many problems, they often express a desire for a revolution. The second interrogative sentence "... where you wan hide your undies?" particularly encodes an explicit attitude of oppression/frustration in its highest degree. When people become tired of an oppressive system, they tend to throw its yoke off their shoulder. The interrogation "How careful can you be?" shows that the nation's rebirth must entail a serious radical approach. In other words, to achieve renaissance, citizens should not be mindful of their lives and properties, religion and God. They should rather be more pragmatically mindful of achieving a just and egalitarian society, devoid of oppression, marginalization, man's inhumanity to man, class segregation, bribery and corruption, nepotism, and political killings, among others. A revolution might not be a magic. In the context of these interrogatives, it could be the deliberate and conscious effort of a people to change the course of their history. And in the words of Gandi, "we must become the change we want to see". Hence, the overall overt attitude from the choice of the interrogations is that of a wakeup call for every citizen of Nigeria to brace up for sociopolitical revolution as soon as practicable if Nigeria should become a better country in the near future.

Also, in comment 9 above, the rhetorical question "Is this act a by-product of anxiety?" is an indexical representation of worry, which evokes a feeling of chronophobia. Chronophobia is the persistent and often irrational fear of the future or the fear of passing time. Almost everybody worries about what will happen in the future. In other word, everybody has some level of anxiety. Meanwhile, when the future becomes clearly uncertain, like what is obtainable in the Nigerian nation at the moment, anxiety disorder sets in. The people become consistently worried about what they will eat, what they will drink, what they will wear, what to spend, employment after schooling. The thought of how to satisfy those needs occasionally lures people into crime. There is thus an attitude of hopelessness with uncertainty from the interrogative expression.

8. TABLE 3: THREAD 3: Lady Claims her Friend's Panties were Sold for Rituals; Breaks Down in Tears-Feb. 22, $\underline{2019}$

\begin{tabular}{|l|l|}
\hline Comment 11 & $\begin{array}{l}\text { What a country!!! That people believe one can get rich through rituals; use a lady'spant to } \\
\text { make money; make a female barren using her undies, tells you a lot about the quality of } \\
\text { education obtained and how archaic their cerebrum is.-Gerrad 59 (m) }\end{array}$ \\
\hline Comment 12 & $\begin{array}{l}\text { When Flavour, our musician prophesiedabout the" Panty no nairo", we were never } \\
\text { listening to the meaning-Dear Lord (m). 10:52 pm,Nov 2, 2018. }\end{array}$ \\
\hline Comment 13 & $\begin{array}{l}\text { Money is truly the root of all evil. This can only happen in Nigeria. Useless set of people. } \\
\text { How do you sell pant to ritualist? I tire ooo.-Jacob (m) 6:23 am }\end{array}$ \\
\hline Comment 14 & So,anything that happens to Nigerian ladies now is Yahoo Boys. Na waoooooo. \\
\hline Comment 15 & $\begin{array}{l}\text { No pity these lazy slay queens, cosnawetindey want them get. I have tried to advise ladies } \\
\text { but they don't want to hear. So, nothing concerns me again. Na who river sees his leg, } \\
\text { nahimit will swallow. }\end{array}$ \\
\hline
\end{tabular}

\subsection{Symbolism as provocation of stereotypical attitudes and fantasies}

From semiotic perspective, symbolism denotes a sign (signifier) whose relationship to its object (signified) is entirely arbitrary or based on convention. 
In comment 11, the symbolic expression, "What a country" is a bricolage of Achebe's There was a country, a lament for the decline of Nigeria. This memoir of Achebe's early life recalls some nationalists' (Achebe inclusive) pains, struggles and a strong desire for independence after Nigeria had been under British colonial rule since 1914. The book recalls how the country eventually won its freedom in 1960 and how there was great hope in the sovereign nation that the lives of its people would be enriched and their futures bright and hopeful. Meanwhile, after a few years of sociopolitical and economic comfort, the nation quickly devolved into abyss due to political leadership failure, corruption and bent toward ethnic oppression. The attitude from the symbol of a country in this comment is the one of disillusionment as well as regret. It is a clear indication that Nigeria was once a great nation, where things were rosy, with a graceful economy, before things went from bad to worse, basically as a result of successive political leadership failure.

The symbolism of "money" in comment 13 is a representation of an attitude of justification, which suggests that everyone in life desires to be rich. The money signifier occupies a paratopic space, where a qualifying test takes place. Meanwhile, competence is required to excel in this space. The commenter is indirectly saying that nobody should be blamed when it comes to money matters because everyone desires it. There is a clear indifferent attitude here. At the extended level of representation, "money" is a god. The Yoruba axiomatic expression "Money for hand, back for ground" explains the indispensability of money.

Similarly, Orlando Owoh's 1984 philosophical album "Money Palava" shows that money is an answer to all things and should be worshipped. In modern society, money seems to be the most dynamic element in the economy. It influences not only the level of prices but also the cyclical behavior of consumption, savings, investment and employment. A well-conceived and well-executed monetary policy is therefore considered as an essential pre-requisite for the stable and efficient working of any national economy. The commenter's attitude of justification is also revolutionary as it implies that money should not be a unilateral thing but should rather cut across class and sections of the society.

\section{Conclusion}

We try in this study to interrogate Internet discourses (i.e. news reports and readers' comments) on crime related threads on Nairaland, using critical social semiotic approach. The study shows the nexus between attitude and language in communicative behaviours and more interestingly at explicit level. Online users are perhaps ruthless and assertive in an attempt to express affective meaning. From our findings, some of these attitudes depict pity, pain and fear. Some are sarcastic and condemnatory in orientation while most comments purge certain feelings of revolutionary, rejection and distortion in social order. Commenters balance their arguments, because, while some comments are expository and revolutionary in nature, there are some elements of explicit justifications of the actions of the criminals in some other comments. Not many of the commenters are against crime, but very many of them seem to suggest that the solution to the subject of criminality is not in the hands of individuals; it lies in the hands of government. Hence, the online environment has provided a semiotic space for people to register their involvement in the socio-political and economic events of the country.

\section{References}

Achi, P.S. (2008).A Pragma-Semiotic Analysis of Graffiti of Kaduna Polytechnic Students. Master's Dissertation, Ahmadu Bello University, Zaria.

Achumba, I.C., Ighomereho, O.S., \&Akpor-Robaro, M.O. (2013).Security Challenges in Nigeria and the Implications for Business Activities and Sustainable Development.Journal of Economics and Sustainable Development, Vol. 4, No. 2.

Adegbite, W. \&Odebunmi, A. (2006). Discourse Tact in Doctor-Patient Interactions in English: An Analysis of Diagnosis in Medical Communication in Nigeria. Nordic Journal of African Studies, 15(4):499-519

Adegoju, A. (2011). Gender Stereotyping in Ola Rotimi's Man Talk, Woman Talk: A Social Semiotic Reading.Journal of English Studies, Vol. 28(1):73-84

Adegoju, A. (2016) "We have to tell our story": semiotics of resisting negative stereotypes of Nigeria in the heart of Africa nation branding campaign. Social Semiotics, vol. 27(2): 158-177.

Adegoju, A. \&Ademilokun, M. (2015). Verbal and visual signifiers of Advertising shares offer in Nigeria's 2005 bank recapitalization. Discourse and Communication.Vol. (9) 5, 519-533.

Adeleke, A. (2013). Insecurity: A Threat to Human Existence and Economic Development in Nigeria. Journalof Public Policy and Administration Research, Vol. 3, No.6. 
Ademilokun, M. \&Olateju, M. (2016). A Multimodal Discourse Analysis of some visual Images in the Political Rally Discourse of 2011 Electioneering Campaigns in Southwestern Nigeria. International Journal of Society, Culture and Language, vol. 5(3).

Afzal, M.T. \&Harun, N.Y. (2015). Advances in Environmental Biology.AENSI Journals, 9(15), 34-40.

Bennett, J. (2011). A Critical Social Semiotic Study of the Word Chav in British Written Public Discourse, 20048.(Doctoral dissertation).Available from University of Birmingham Research Archive e-theses repository. (I.D: 2007/134908)

Chiluwa, I. (2010). Nigerian English in informal email messages. English World-Wide, vol. 31 (1), pp. 40-61.

Coulthard, C.R., \&Leeuwen, T.V. (2003). "Critical Social Semiotics: Introduction.” Social Semiotics, Vol.13 (1):3-27.

Ezeifeka, C.R. (2013). Critical Discourse Analysis of Interpersonal Meaning and Power Relations in selected Inaugural Political Speeches in Nigeria. Unizik Journal of Arts and Humanities, vol. 5(6)

Fundamental Rights.Constitution of the Federal Republic of Nigeria (1999). Fourth Alteration, No.9. LagosNigeria: Law Nigerian Administration

Gandi, M. (1947) Be the Change that you wish to see in the World. Changing the World.Quotable Quotes.

Grunchy, M.I. (2007). AnalysingTasila Do Amaral's Paintings from a Social Semiotic Perspectives.Master's Dissertation, Universidade Federal De Santa Catarina.

Herring, S.C. (2001). "Computer-mediated discourse”. In Tannen, Deborah, Deborah Schiffrin \& Heidi Hamilton (eds.) Handbook of discourse analysis. Oxford: Blackwell. 612-634.

Kathryn, J.B. (2014). Looking at Fashion through Green-coloured Glasses: A Multimodal Critical Discourse Analysis of Vogue's Sustainable Editorials.Doctoral Dissertation, University of Missouri.

Leeuwen, T. (2005).Introducing Social Semiotics. London: Routledge.

Lipsky, D.B. \&Avgar, A.C. (2010). The Conflict over Conflict Management: Dispute Resolution Journal, 65(2-3):3843.

Lirola, M.M. (2016). Multimodal Analysis of a Sample of Political Posters in Ireland during and after the Celtic Tiger.RevistaSignos, 49(91):245-267

Martinec, R. (2003). The Social Semiotics of Text and Image in Japanese and English Software Manuals and other Procedures.Social Semiotics, Vol. 13, No. 1

Mentzer, K. Psychological Effects of the Internet (2003). Retrieved on September 11, 2014 from http://iml.jou.ufl.edu/projects/spring03/Mentzer/advantages.html.

Mutowo, M. (2013). Stylistic and Semiotic Change in Contemporary Painting and Sculpture in Zimbabwe: some perceptions and perspectives. International Journal of Social Science \&Education, Vol.4 (1): 205-213.

Odebunmi, A. (2006). Locutions in Medical Discourse in South-western Nigeria.International Pragmatics Association, 16(1):25-41.

Oha, O. (2000). Signs, cities and designs of capacities: The Semiotics of Road Monuments in some Nigerian cities. The African Anthropologist, Vol. VII, No. 1, pp33-47.

Oha, O. (2006). Well, it is WELL: Language and Human Interest in a Virtual Community. Revista Alicantina de EstudiosIngleses, Vol. 19.

Olaosun, I. E. (2006).Language and Visuality in Selected Commodity Advertisements in some Nigerian Newspapers.Unpublished Ph.D Thesis, Dept. of English, University of Ibadan.

Oyeleye, A.L. \&Osisanwo, A. (2013) Lexicalisation in Media Representation of the 2003 and 2007 General Elections in Nigeria”. World Journal of English Language, Vol.3, No.2.www.sciedu.ca/wjel.

Schaumann, R. (2010). 1941-Design of analog filters. New York: Oxford University Press.

Solomon-Etefia, P.O. \&Nweya, G.O. (2017). A Pragma-semiotic analysis of the Catholic Bishop's communiqué on the Ebola epidemic: Impact on the University of Ibadan Catholic faithful. International Journal of Languages Studies, vol.11 (1):119-142.

Taiwo, R. (2016). Cognitive Verbs and Stance Taking in Nigerian Jobs and Careers Portals Online.Marang: Journal of Language and Literature, vol. 27, 1-19. The Vanguard (Ibadan, Nigeria) 19 January, 2019.

Wennmann, A. (2014). Crime and Conflict. London: Conciliation Resources.

Yeibo, E. (2011) "Figurative Language and Stylistic Functions in J.P. Clark-Bekederemo's Poetry."InAcademic Scholarship. Vol.3: 1-14 